\title{
PENDEKATAN EKO-HABITAT SEBAGAI STRATEGI UNTUK MENINGKATKAN PENDAPATAN MASYARAKAT PERTANIAN
}

\author{
(Eco-habitat Approach as A Strategy to Increase Agricultural Society Income) \\ Priyaji Agung Pambudi* dan Suyud Warno Utomo** \\ Sekolah Ilmu Lingkungan, Universitas Indonesia \\ Jl. Salemba Raya No. 4, Jakarta Pusat \\ *Email: priyajiagungpambudi@gmail.com,**Email: suyudwarno@gmail.com
}

Diterima: 27 Agustus 2019

Direvisi: 7 September 2019

Diterbitkan: 31 Desember 2019

\begin{abstract}
Poverty is an issue that continues to be discussed in the world. Poverty is multi-dimensional and requires the participation of all parties to resolve. Poverty has implications for the environmental damage caused by access to natural resources are made public. This study aims to apply the principles of eco-habitat (integrate economically and ecologically) in rural areas to increase incomes while preserving the environment. The study was conducted with a mixed method through observation, interviews, and literature review. That 68 percent of respondents never perform actions that lead to environmental destruction; 72 percent know that his actions have consequences for the extinction of organisms. Meanwhile, 57 percent say it is because there was another choice for needs. Furthermore, 100 percent of respondents agree with the strategy of environmental conservation by utilizing the types of organisms which has an economic value. Ecological suitability-based land management provides the most optimal production value. Management of pattern and type of land it gives the production value is very small, because of the high cost of planting, pest attacks, and controls that are environmental unfriendly. This should be targeted at land management based ecological suitability to provide economic and ecological values are high. This principle has many benefits including $\mathrm{CO}_{2}$ sequestration, absorb and store water, provide habitat for organisms, and provide economic value for society. Finally, the land use pattern encourages a sense of ownership of natural resource and environmental ecosystems, that they have the willingness to manage and preserve it.

Keywords: agriculture, ecosystems, environmental degradation, income, poverty
\end{abstract}

\begin{abstract}
Abstrak
Kemiskinan menjadi isu yang terus diperbincangkan di seluruh belahan dunia, yang harus diselesaikan pada tahun 2030. Kemiskinan bersifat multi dimensi dan membutuhkan partisipasi dari semua pihak untuk menyelesaikannya. Kemiskinan berimplikasi pada terjadinya kerusakan lingkungan akibat akses sumber daya alam yang dilakukan masyarakat. Penelitian ini bertujuan untuk menganalisis penerapan prinsip eko-habitat (mengintegrasikan aspek ekonomi dan ekologi) di kawasan pedesaan untuk meningkatkan pendapatan masyarakat sekaligus melestarikan lingkungan. Penelitian dilakukan dengan mixed method melalui observasi, wawancara, dan kajian pustaka. Berdasarkan hasil penelitian diketahui bahwa 68 persen responden pernah melakukan tindakan yang mengarah pada perusakan lingkungan; 72 persen mengetahui bahwa tindakannya memiliki konsekuensi terhadap kepunahan organisme. Sementara 57 persen menyatakan hal tersebut dilakukan karena tidak ada pilihan lain untuk memenuhi kebutuhan hidup. Di sisi lain, 100 persen responden setuju dengan strategi pelestarian lingkungan dengan memanfaatkan jenis-jenis organisme yang bernilai ekonomi. Pengelolaan lahan berbasis kesesuaian ekologis memberikan nilai produksi yang paling optimal. Pola pengelolaan dan jenis lahan yang justru memberikan nilai produksi yang sangat kecil, karena tingginya biaya tanam, serangan organisme pengganggu tanaman, dan pengendalian yang tidak ramah lingkungan. Perlu diutamakan pengelolaan lahan berbasis kesesuaian ekologis untuk memberikan nilai ekonomi dan ekologi yang tinggi. Tentunya prinsip ini memiliki banyak manfaat di antaranya menyerap $\mathrm{CO}_{2}$, menyerap, dan menyimpan air, menyediakan habitat organisme, dan memberikan nilai ekonomi bagi masyarakat. Pada akhirnya dengan pola pemanfaatan lahan tersebut masyarakat memiliki rasa kepemilikan terhadap ekosistem alam dan lingkungan, sehingga mereka memiliki kemauan untuk menjaga dan melestarikannya.
\end{abstract}

Kata kunci: ekosistem, kemiskinan, kerusakan lingkungan, pendapatan, pertanian

\section{PENDAHULUAN}

Pertumbuhan penduduk yang terus meningkat menimbulkan risiko terhadap kelestarian flora dan fauna (Lund, 2017). Populasi manusia khususnya kondisi sosial ekonomi yang melekat di dalamnya dianggap sebagai faktor pendorong utama terjadinya degradasi lingkungan (Rajan, 2018). Terkait dengan hal tersebut kemiskinan menjadi salah satu faktor penting yang mendorong terjadinya proses degradasi lingkungan. Meskipun demikian, pada kenyataannya terdapat faktor lain yang menyebabkan degradasi lingkungan, yakni penyimpangan dalam aktivitas pembangunan, produksi, distribusi, dan konsumsi yang berimplikasi terhadap degradasi di berbagai sektor (Sriyanto, 2007). Di sisi lain, sektor yang paling berkontribusi terhadap degradasi kualitas lingkungan adalah eksploitasi hutan dan industri pertambangan (Nurhayati, et al., 2017). Secara mendasar berbagai faktor pendorong terjadinya degradasi lingkungan diakibatkan oleh aktivitas manusia dalam pemenuhan kebutuhan pangan, energi, dan berbagai hal lain yang terkait erat dengan aktivitas kesehariannya. Oleh 
karena itu, lingkungan alam yang memiliki segala hal baik komponen biotik maupun abiotik menjadi objek yang terdampak.

Pada dasarnya lingkungan khususnya lahan memang menyediakan sumber daya alam yang sangat melimpah, sehingga hal tersebut tidak dapat dihindari. Ekosistem lahan memiliki nilai sosial, ekonomi, dan lingkungan yang sangat besar dan penting bagi keberlanjutan suatu kawasan atau bahkan suatu negara (Mourao \& Martinho, 2019). Namun demikian, lahan dan hutan seringkali mendapatkan tekanan khususnya dari aktivitas antropogenik manusia, sebagai contoh pembakaran lahan, penggunaan pestisida, pupuk anorganik berlebihan, dan intensifikasi tanpa memerhatikan kesesuaian ekologi (Mourao \& Martinho, 2016). Padahal Indonesia sebagai negara agraris yang memiliki kesuburan tinggi seharusnya tidak perlu diintervensi dengan berbagai hal yang mengarah pada eksploitasi sumber daya lahan tersebut.

Indonesia adalah negara pertanian yang apabila ditinjau dari ilmu geografi, ekologi, sosial, dan budaya sangat potensial. Indonesia dengan segala potensi pertaniannya termasuk jenis tanah, bahan induk, topografi, elevasi, dan iklim menjadi modal besar untuk memproduksi pertanian secara berkelanjutan (Hidayat, 2009). Kekayaan sumber daya alam termasuk kesuburan lahan di dalamnya perlu dipahami dengan baik tidak hanya sebatas lahan sebagai bentuk fisik saja, tetapi juga berbagai hal yang menyertainya. Pemahaman mengenai ekosistem lahan yang menjadi habitat bagi agrobiodiversity akan mendorong manusia untuk mengelola lahan berlandaskan pada kesesuaian ekosistem (Béné, et al., 2019). Pengelolaan lahan berbasis kesesuaian ekosistem seharusnya dipahami oleh masyarakat secara luas (Global Panel, 2016) karena sistem pertanian dan sistem pangan yang berlangsung dalam beberapa dekade terakhir sebenarnya kurang ideal.

Sistem produksi menjadi salah satu sentral kegagalan karena umumnya hanya berorientasi pada produksi maksimal tanpa memperdulikan kesesuaian ekosistem dan lingkungan (FAO, 2016; Haddad \& Hawkes, 2016; IPES, 2016; Biel, 2016). Fenomena tersebut juga terjadi di Indonesia di mana kawasan hutan yang khas dengan keanekaragaman tumbuhan justru dikonversi menjadi lahan pertanian monokultur (Widianto, et al., 2004) dan menjadi kawasan industri baik pertambangan maupun industri hasil hutan kayu (Pagiola, 2000). Tingginya eksploitasi menimbulkan tekanan bagi ekosistem hutan yang berdampak terhadap menurunnya kuantitas dan kualitas ekosistem (Kartodohardjo dan Supriono, 2000). Secara khusus mekanisme konversi hutan menjadi lahan pertanian monokultur tidak sesuai dengan karakteristik lahan dan ekosistemnya, sehingga membutuhkan biaya yang besar dalam pengelolaan lahan monokultur. Secara tidak disadari justru hal inilah yang menjadi hambatan untuk mengembangkan sektor pertanian di Indonesia. Ketidaksesuaian lahan pertanian dengan jenis tanaman budidaya membebankan biaya produksi pertanian. Biaya produksi tersebut terutama untuk merawat tanaman budidaya yang secara khusus ditujukan pada aspek pengendalian tumbuhan pengganggu (Pambudi, et al., 2019).

Pengendalian tumbuhan pengganggu tidak hanya mengakibatkan tingginya biaya produksi pertanian, tetapi banyak faktor yang terimplikasi dari pengendalian organisme tumbuhan pengganggu tersebut di antaranya adalah risiko kematian organisme non-target, pencemaran tanah, pencemaran air, risiko kematian tanaman budidaya, dan meningkatnya emisi gas rumah kaca (Wakabayashi \& Böger, 2002; Meyerová, et al., 2018). Berdasarkan penelitian yang dilakukan oleh Pambudi \& Waryono (2018) diketahui bahwa pengendalian tumbuhan pengganggu pertanian padi lahan kering berkontribusi terhadap emisi sebesar $4,4 \times 10^{1} \mathrm{~kg}$ $\mathrm{CO}_{2} \mathrm{eq} / \mathrm{ha}$. Besarnya emisi yang dihasilkan oleh aktivitas pengendalian tumbuhan pengganggu turut berkontribusi terhadap perubahan iklim global yang mengancam kehidupan manusia dan ekosistem.

Selain berbagai risiko yang ditimbulkan dari proses pengendalian tumbuhan pengganggu, penerapan pertanian monokultur juga menimbulkan risiko ekologis hilangnya habitat dan relung berbagai jenis organisme (Thayib, 2018). Konversi hutan yang kaya akan keanekaragaman hayati menjadi lahan monokultur mengakibatkan degradasi lahan baik komponen biologi, fisik, maupun kimia. Hal tersebut mengakibatkan menurunnya fungsi ekosistem alam sebagai penyerap karbondioksida atau yang umum disebut sebagai kolam karbon (Pambudi, et al., 2017). Oleh karena itu, pengelolaan lahan harus berdasarkan prinsip kesesuaian ekologis untuk mengurangi atau bahkan menghilangkan risiko degradasi lingkungan. Terlebih pengelolaan lahan yang bersifat monokultur tidak mencerminkan sistem pengelolaan lahan yang berkelanjutan karena tidak sesuai dengan kondisi ekologis di Indonesia.

Kesesuaian pengelolaan lahan pertanian menjadi faktor yang harus dikedepankan untuk mewujudkan pertanian yang berkelanjutan. Faktor-faktor yang harus dikedepankan terkait dengan kesesuaian tersebut meliputi kondisi iklim, ketersediaan unsur hara, lansekap dan topografi, hidrologi, persyaratan sosial, ekonomi, dan teknis. Faktor sosial penting untuk diperhatikan karena pada dasarnya faktor 
sosial dan ekonomi masyarakat lokal yang melekat dengan satu kesatuan kawasan lahan pertanian harus dapat diakomodasi dan dikedepankan (Akpoti, et al., 2019). Seiring dengan berkembangnya ipteks, pengarusutamaan kesesuaian lahan mulai menjadi prioritas dalam praktik pertanian karena paradigma pertanian modern tidak lagi semata berorientasi untuk menghasilkan produk sebanyak-banyaknya guna memenuhi kebutuhan populasi penduduk yang terus meningkat, tetapi juga untuk mengurangi dampak lingkungan (Smith, 2013; Rótolo, et al., 2015; Mosleh, et al., 2017). Melalui hal tersebut praktik pertanian tidak hanya beorientasi pada produksi tetapi juga keberlanjutan produksi di masa mendatang. Tentunya keberlanjutan produksi sangat ditentukan oleh pola pengelolaan lahan pertanian yang dilakukan saat ini.

Upaya yang dilakukan untuk mewujudkan pertanian yang berkelanjutan dapat dicapai dengan implementasi paradigma pertanian modern. Paradigma ini perlu dipraktikkan secara masif untuk meningkatkan ketahanan pangan saat ini dan masa depan melalui pengelolaan sumber daya lahan secara efisien (Bonfante, et al., 2018). Hal tersebut perlu dipahami karena pengembangan pertanian yang berkelanjutan untuk memastikan ketahanan pangan dapat dicapai melalui pengelolaan sumber daya lahan yang efisien berdasarkan kesesuaian lahannya (Kihoro, et al., 2013; Montgomery, et al., 2016). Melalui implementasi sistem pertanian berbasis kesesuaian lahan juga berperan untuk meningkatkan pendapatan petani karena tanaman budidaya menjadi lebih produktif (Gaffney, et al., 2019). Salah satu implementasi paradigma pertanian modern adalah praktik pertanian berbasis agroforestri. Berdasarkan hasil penelitian tentang pengembangan model pengelolaan lahan marginal yang dilakukan oleh Tsonkova, et al. (2013) dapat ditarik kesimpulan sebagai berikut (1) model pengembangan agroforestri oleh masyarakat di sekitar kawasan hutan secara tumpang sari dapat meningkatkan penghasilkan dan kesejahteraan mereka dengan $\mathrm{B} / \mathrm{C}$ ratio padi (3.091), jagung (2.288), kacang tanah (2.809), (2) model pengembangan agroforestri dapat memengaruhi pertumbuhan dan perkembangan tanaman pokok, dan (3) dapat meningkatkan kesadaran masyarakat sekitar hutan untuk menjaga kesuburan lahan. Hal tersebut menjadi poin penting yang harus dipahami oleh masyarakat agar praktik pertanian konvensional beralih ke sistem pertanian berkelanjutan berbasis agroforestri karena memberikan manfaat yang lebih besar.

Sejalan dengan semakin kompleksnya persoalan lingkungan maka praktik pertanian sudah seharusnya memerhatikan kesesuaian lahan termasuk di dalamnya memanfaatkan lahan yang belum dikelola untuk budidaya tanaman yang sesuai. Oleh karena itu, penelitian ini bertujuan untuk menganalisis sistem pengelolaan lahan melalui pendekatan ekohabitat dalam rangka meningkatkan pendapatan masyarakat sekaligus melestarikan lingkungan (konservasi). Melalui hal tersebut risiko degradasi lingkungan dapat dikurangi atau bahkan dihindarkan.

\section{METODE}

Penelitian ini menggunakan pendekatan kualitatif yang bertujuan untuk menjelaskan persoalan pengelolaan lahan kaitannya dengan degradasi kualitas lingkungan. Data penelitian diperoleh melalui observasi, wawancara, dan studi literatur. Penelitian dilakukan di Kecamatan Ngadirojo, Kabupaten Pacitan dan Kecamatan Pule, Kabupaten Trenggalek pada Oktober 2018-Maret 2019 dengan responden wawancara tertutup sebanyak 130 orang dan responden wawancara mendalam sebanyak 18 orang. Penentuan sampel tersebut berdasarkan purposive sampling dengan kriteria (1) masyarakat pemilik lahan, (2) sudah tinggal dilokasi penelitian setidak-tidaknya 5 tahun, dan (3) kepala keluarga. Observasi dilakukan di kedua kecamatan tersebut dengan cara mengamati kondisi lingkungan khususnya pola pemanfaatan lahan pertanian (jenis tanaman, pemupukan, pengendalian organisme pengganggu tanaman (OPT), dan produksinya), keberadaan kawasan hutan dan pengelolaannya, dan pola interaksi masyarakat dengan lingkungan sekitar.

Pemanfaatan lahan dalam penelitian ini dikategorikan menjadi 3, yaitu (1) monokultur, pemanfaatan lahan hanya dengan 1 jenis tanaman untuk sekali musim tanam, (2) multikultur, pemanfaatan lahan dengan $\geq 2$ jenis tanaman yang memiliki kategori sama (tanaman semusim) untuk sekali musim tanam, dan (3) tumpang sari, pemanfaatan lahan dengan $\geq 2$ jenis tanaman yang terdiri atas tanaman semusim dan tanaman menahun dalam satu lahan.

\section{HASIL DAN PEMBAHASAN}

Observasi yang dilakukan untuk mengetahui pola pemanfaatan lahan menunjukkan bahwa masyoritas masyarakat yang tinggal di kawasan perdesaan memiliki tingkat penghasilan yang terbilang rendah karena berada di bawah nominal Upah Minimum Regional (UMR) di kabupaten lokasi penelitian. Selain itu, mayoritas masyarakat masih menggantungkan hidupnya pada sektor pengelolaan lahan atau bertani. Rerata penghasilan responden sebesar Rp1.000.0001.750.000 per bulan. Rendahnya penghasilan yang mereka dapatkan berpengaruh terhadap 
upaya pemenuhan kebutuhan hidup sehari-hari. Kondisi ini menjadi faktor pendorong perilaku yang mengarah pada perusakan lingkungan, misalnya mengeksploitasi kayu di hutan untuk dijual sebagai kayu bakar atau bahan bangunan, menangkap satwa untuk dijual (ayam alas dan berbagai jenis burung), dan menangkap ikan dengan cara yang tidak ramah lingkungan. Pola perilaku dan interaksi manusia dengan lingkungan seperti ini menunjukkan bahwa pada dasarnya manusia masih mengedepankan prinsip antroposentrisme. Sehingga mereka merasa paling berhak untuk mengeksploitasi sumberdaya alam sebanyak-banyaknya untuk kepentingan dirinya. Hal seperti ini seharusnya tidak lagi dilakukan karena lingkungan memiliki daya dukung dan daya tampung yang terbatas dan tidak dapat dilampaui agar ekosistem tetap stabil.

Namun demikian, mayoritas responden menyampaikan bahwa sebenarnya mereka mengetahui jika yang dilakukannya memiliki konsekuensi terhadap kepunahan organisme. Tetapi mereka menyampaikan bahwa tidak ada pilihan lain demi memenuhi kebutuhan hidup sehari-hari. Oleh karena itu, masyarakat di lokasi penelitian secara mendasar masih memiliki rasa kepedulian terhadap lingkungan. Akan tetapi, faktor ketiadaan mendorong masyarakat untuk terus berusaha mengeksploitasi alam. Hal tersebut tentunya dapat dikurangi atau bahkan dihilangkan jika masyarakat diberdayakan, sehingga ada pendapatan rutin yang diperoleh untuk memenuhi kebutuhan hidupnya. Terkait dengan kondisi tersebut seluruh responden setuju dengan strategi optimalisasi pendapatan yang sekaligus berperan untuk mengkonservasi lingkungan. berikut pada Tabel 1 data umum mengenai responden.

Berdasarkan Tabel 1 dapat diketahui bahwa masyarakat di lokasi penelitian sedang berada pada

Tabel 1. Data Umum Responden

\begin{tabular}{lll}
\hline No. & \multicolumn{1}{c}{ Indikator } & \multicolumn{1}{c}{ Hasil } \\
\hline 1. & $\begin{array}{l}\text { Rerata penghasilan } \\
\text { responden }\end{array}$ & $\begin{array}{l}\text { Rp1.000.000-1.750.000 per } \\
\text { bulan }\end{array}$ \\
2. & $\begin{array}{l}\text { Tindakan yang } \\
\text { mengarah pada } \\
\text { perusakan lingkungan }\end{array}$ & $\begin{array}{l}\text { 68 persen pernah } \\
\text { melakukan, 15 persen tidak } \\
\text { pernah, 17 persen ragu }\end{array}$ \\
3. & $\begin{array}{l}\text { Mengetahui } \\
\text { konsekuensi dari } \\
\text { tindakan yang mengarah } \\
\text { pada perusakan } \\
\text { lingkungan }\end{array}$ & $\begin{array}{l}\text { 72 persen mengetahui, 28 } \\
\text { persen tidak mengetahui }\end{array}$ \\
Motif tindakan yang & \\
& berpotensi merusak \\
lingkungan & 57 persen tidak ada pilihan \\
& & $\begin{array}{l}\text { lain untuk kebutuhan } \\
\text { sehari-hari, 25 persen hobi } \\
\text { koleksi flora dan fauna, 18 } \\
\text { persen sebagai dampak dari } \\
\text { aktivitas yang dilakukan }\end{array}$ \\
&
\end{tabular}

kondisi yang dilematis. Persoalan dilematis tersebut di antara pilihan mempertahankan kelestarian lingkungan tetapi kehidupannya serba kekurangan termasuk kebutuhan pangan atau memenuhi kebutuhan pangan tetapi mengorbankan lingkungan. Disadari atau tidak, hingga saat ini masih banyak masyarakat yang tinggal di kawasan pelosok hidup serba dalam keterbatasan dan menggantungkan sepenuhnya terhadap lingkungan. Hal ini sesuai hasil penelitian yang dilakukan oleh Nurrani \& Tabba (2013) bahwa masyarakat yang memiliki tempat tinggal berbatasan dengan kawasan hutan memiliki ketergantungan dengan sumber daya hutan untuk memenuhi kebutuhan hidupnya. Kondisi yang terdapat di lokasi penelitian adalah mayoritas lahan kering (kurang subur dan defisit air) dan sistem irigasi belum dikelola dengan baik. Akhirnya lahan pertanian hanya dapat ditanami dengan komoditas penghasil makanan pokok sebanyak satu kali dalam satu tahun, selebihnya ditanam jenis palawija dan dibiarkan bera (lahan secara sengaja tidak ditanami karena kondisi lingkungan tidak mendukung terjadinya pertumbuhan). Kondisi tersebut sesuai dengan hasil penelitian dari Pambudi \& Waryono (2018) di mana petani lahan kering memilih untuk tidak mengelola lahannya apabila kondisi iklim mikro sangat ekstrim. Oleh karena itu, masyarakat berusaha menanam suatu jenis komoditas tertentu untuk memproduksi tanaman pangan dalam jumlah yang besar. Tentu harapannya produksi panen dapat digunakan untuk memenuhi kebutuhan dalam satu musim berikutnya. Dengan demikian pengelolaan lahan pertanian akan cenderung homogen dan penanaman dilakukan secara serentak.

Lahan sawah yang dimaksud dalam penelitian ini adalah suatu kawasan lahan yang memiliki sistem irigasi sangat baik, sehingga lebih dari setengah waktu dalam setahun selalu tergenang. Selain itu, lahan sawah juga dimanfaatkan secara intensif untuk jenis tanaman pangan musiman (padi, jagung, kedelai, dan lain sebagainya). Lahan perkebunan yang dimaksud dalam penelitian ini adalah suatu kawasan lahan yang pada musim tertentu dapat tergenang oleh air, tetapi pada musim lainnya mengering. Di sisi lain, lahan perkebunan adalah jenis lahan yang dikelola secara intensif, umumnya untuk budidaya tanaman pangan, sayuran, atau buah-buahan. Lahan tegal yang dimaksud dalam penelitian adalah suatu kawasan lahan yang tidak pernah tergenang oleh air sepanjang musim. Selain itu, lahan ini tidak dikelola secara intensif, melainkan hanya dimanfaatkan untuk menanam jenis-jenis tanaman menahun umumnya buah-buahan dan pepohonan berkayu. Lahan tidur yang dimaksud dalam penelitian ini adalah kawasan lahan yang sepanjang tahun tidak pernah tergenang 
Tabel 2. Pemanfaatan Lahan di Kecamatan Ngadirojo dan Kecamatan Pule

\begin{tabular}{llrrrr}
\hline \multicolumn{1}{c}{ Lokasi } & $\begin{array}{c}\text { Jenis Pemanfaatan } \\
\text { Lahan }\end{array}$ & $\begin{array}{c}\text { Lahan Sawah } \\
\text { (persen) }\end{array}$ & $\begin{array}{c}\text { Lahan Perkebunan } \\
\text { (persen) }\end{array}$ & $\begin{array}{c}\text { Lahan Tegal } \\
\text { (persen) }\end{array}$ & $\begin{array}{c}\text { Lahan Tidur } \\
\text { (persen) }\end{array}$ \\
\hline \multirow{2}{*}{ Kec. Ngadirojo } & Monokultur & 100 & 55 & 12 & 18 \\
& Multikultur & 0 & 35 & 36 & 74 \\
& Tumpang sari & 0 & 10 & 52 & 8 \\
Kec. Pule & Monokultur & 100 & 48 & 8 & 12 \\
& Multikultur & 0 & 22 & 37 & 78 \\
\hline
\end{tabular}

Sumber: Data Primer Penelitian 2018-2019.

air dan tidak dimanfaatkan untuk fungsi pertanian (dibiarkan menjadi lahan kosong).

Mayoritas responden di lokasi penelitian mengelola lahan dengan cara monokultur pada lahan persawahan dan multikultur pada lahan perkebunan. Namun demikian, pola pemanfaatan lahan dengan cara agroforestri atau tumpang sari juga sudah dilakukan walaupun hanya sedikit. Pengelolaan lahan berbasis agroforestri atau lazim dikenal dengan tumpang sari ini perlu diterapkan secara optimal untuk menunjang produksi pertanian bagi masyarakat di lokasi penelitian yang umumnya lahan di kawasan ini memiliki kesuburan yang relatif rendah dan tipe lahan marginal. Pengelolaan berbasis agroforestri memberikan manfaat yang lebih komprehensif baik bagi kondisi sosial ekonomi masyarakat maupun untuk lingkungan (Tsonkova, et al., 2013). Berikut pada Tabel 2 ditampilkan data pemanfaatan lahan di Kecamatan Ngadirojo dan Kecamatan Pule Kabupaten Trenggalek.

Berdasarkan hasil observasi pemanfaatan lahan dapat diketahui bahwa di kedua kecamatan tersebut pemanfaatan lahan secara umum yang dominan diterapkan adalah monokultur dan multi kultur. Pada lahan sawah 100 persen responden menyatakan bahwa hanya dimanfaatkan untuk satu jenis tanaman saja yaitu padi pada musim penghujan dan kedelai atau jagung pada musim kemarau. Petani memilih menanam padi pada saat musim hujan karena jenis tanaman ini adalah makanan pokok masyarakat setempat, sehingga padi ditanam untuk memenuhi kebutuhan pangan keluarga dan apabila berlebih baru akan dijual. Pernyataan petani tersebut sejalan dengan hasil penelitian Pambudi, et al. (2019) yang menyatakan bahwa petani dengan jumlah lahan terbatas akan cenderung memanfaatkan hasil panen untuk memenuhi kebutuhan keluarga. Sementara pada saat musim kemarau petani memilih kedelai dan jagung untuk di budidayakan karena kedua jenis tanaman ini menjadi tanaman pangan penunjang pangan pokok. Di sisi lain, cukup banyak industri dengan bahan baku kedelai dan jagung di sekitar lokasi riset (Diskoperindag Kab. Pacitan, 2015) sehingga serapan pasar terhadap komoditi tersebut sangat baik. Dengan demikian petani lebih mudah untuk menjual hasil panennya.

Walaupun lahan sawah dominan ditanami secara monokultur, di lokasi ini lahan perkebunan sedikit berbeda dalam hal pola pemanfaatannya. Lahan perkebunan dikelola oleh masyarakat sedikit lebih bervariasi dibandingkan dengan lahan sawah. Jenis lahan ini dimanfaatkan oleh pemilik lahan secara lebih bervariasi yakni monokultur sebanyak 55 persen, multikultur 35 persen, dan tumpang sari 10 persen. Sebagaimana penelitian dari Sahara dan Kushartanti (2019) di lokasi ini lahan perkebunan juga masih ada yang ditanami dengan padi gogo. Kondisi tersebut menunjukkan bahwa terjadi sistem pergiliran tanaman dan sekaligus tidak berfokus pada satu jenis tanaman saja. Perlu diketahui bahwa masyarakat di lokasi penelitian umumnya menanam palawija di lahan perkebunan sepanjang tahun yang terbagi menjadi 3 fase tanam yakni bulan DesemberMaret, April-Juli, dan Agustus-November. Pada masa tanam pertama (Desember-Maret) umumnya petani menanam kacang tanah saja. Meskipun demikian, beberapa di antaranya menanam kacang tanah sebagai tanaman pokok dan ketela pohon sebagai tanaman pelengkap yang di tanam di tepian lahan ( 2 baris tanaman ketela pohon), serta kacang panjang yang ditanam di tengah dan tepian lahan ( 3 baris tanaman kacang panjang). Di sisi lain, 10 persen petani yang menerapkan pola tanam tumpang sari umumnya menambahkan jenis tanaman sengon laut, kelapa, pisang di salah satu ujung lahan perkebunannya. Pola yang diadopsi oleh petani dalam pemilihan lahan tersebut sejalan dengan hasil penelitian dari Akpoti, et al. (2019) yang menyatakan bahwa petani memiliki kemampuan yang sangat baik untuk menentukan jenis tanaman dengan kesesuaian lahan yang digarapnya. Responden menyatakan bahwa pola monokultur dan/atau multikultur dengan sedikit variasi tanaman (maksimal 3 jenis tanaman) dipilih karena lebih efisien dalam hal penyediaan benih, perawatan, hingga pemanenan. Oleh karena itu, mayoritas responden memilih menanam satu 
jenis tanaman saja dalam satu petak lahan yang dimilikinya.

Tren yang berbeda terlihat pada jenis lahan tegal yang di kedua lokasi menunjukkan bahwa pemanfaatan secara tumpang sari lebih dominan (52 persen). Berdasarkan hasil wawancara diketahui bahwa masyarakat memilih pola tersebut karena pertimbangan lahan tegal dianggap tidak lebih subur dibandingkan dengan lahan sawah dan perkebunan. Oleh karenanya, masyarakat memilih menanam beberapa jenis tumbuhan berkayu dan berhabitus pohon yang dianggap tidak memerlukan perawatan yang intensif. Hal tersebut dilakukan oleh masyarakat karena lahan tegal pada dasarnya memiliki tingkat kesuburan yang berada di bawah lahan sawah dan perkebunan. Dengan demikian jenis tanaman musiman seperti halnya yang ditanam pada lahan sawah dan lahan perkebunan tidak dapat tumbuh dengan optimal atau bahkan tidak dapat tumbuh sama sekali. Kondisi ini mendorong masyarakat untuk memanfaatkan lahan tegal sebagai lahan budidaya tanaman menahun dan mayoritas berkayu. Prinsip tersebut sesuai dengan konsep pengelolaan lahan secara berkelanjutan yang dikemukakan oleh Smith (2013) bahwa hal terpenting adalah memilih jenis lahan dan pola pengelolaannya berdasarkan karakteristik lahan. Di sisi lain, masyarakat menganggap bahwa pemanfaatan secara tumpang sari akan memberikan saving atau dianggap sebagai tabungan pada saat mereka membutuhkan uang, baru akan menebang pepohonan tersebut. Pada intinya masyarakat menempatkan lahan sawah dan lahan perkebunan untuk menunjang kebutuhan pangan pokok dan penunjangnya serta sektor yang berperan untuk memperoleh active income mingguan dan/atau bulanan. Sementara lahan tegal dijadikan untuk membudidayakan jenis tanaman menahun yang bersifat passive income atau dapat dipanen dalam waktu beberapa tahun kemudian setelah ditanam. Secara mendasar prinsip tersebut telah menggambarkan suatu sistem agribisnis pertanian yang ideal untuk menentukan perolehan pendapatan secara bertahap sebagaimana konsep agribisnis dari Gaffney, et al. (2019). Pola ini diadopsi masyarakat sejak dahulu kala dan hingga saat ini terus diterapkan, karena dianggap bermanfaat jika ada kebutuhan mendadak.

Tumpang sari umumnya diterapkan oleh masyarakat yang tinggal dikawasan lereng pegunungan dengan lahan marginal. Pada kondisi lahan lereng dan/atau marginal pola budidaya pertanian berbasis tumpang sari memberikan banyak keuntungan di antaranya pada saat terjadi musim penghujan risiko banjir dan tanah longsor dapat diminimalisir, struktur tanah lebih stabil, dan pada saat musim kemarau lahan tetap dalam kondisi yang lembab. Mekanisme tersebut berperan untuk konservasi tanah dan air (Karuniasa \& Pambudi, 2019). Dengan demikian dapat diketahui bahwa masyarakat di lokasi penelitian telah memiliki kapasitas pengetahuan pengelolaan lahan pertanian secara mendalam. Oleh karena itu, pemanfaatan lahan untuk budidaya pertanian disesuaikan dengan karakteristik iklim mikro dan topografi lahan.

Kondisi tersebut tidak diterapkan 100 persen oleh masyarakat di lokasi penelitian karena masyarakat yang memiliki lahan lebih subur memilih pola monokultur dan multikultur. Secara mendasar pola yang diterapkan tersebut sudah mengarah pada kesesuaian ekologis. Terlebih dari aspek tata cara pengelolaan lahan dan waktu penanaman. Namun demikian, masih perlu diperhatikan dan dikaji secara mendalam terkait konteks pemilihan jenis tanaman di setiap musim tanamanya apakah jenis tanaman yang dipilih sudah sesuai dengan kondisi ekologis atau belum. Pasalnya pola yang memiliki kesesuaian dengan kondisi ekologis harus ditunjang dengan pemilihan jenis tanaman yang juga sesuai secara ekologis (Thayib, 2018). Apabila salah satu dari kedua komponen tersebut tidak diterapkan maka yang terjadi adalah biaya produksi pertanian yang tinggi, gangguan OPT lebih masif, dan produksi kurang optimal. Berikut adalah jenis tanaman yang dibudidayakan pada berbagai jenis lahan di lokasi penelitian.

Jenis-jenis tanaman yang dibudidayakan oleh masyarakat pada berbagai jenis lahan di kedua lokasi penelitian secara umum memiliki kesamaan, yakni tanaman pangan dan tanaman sayur serta beberapa jenis tanaman kayu yang dikenal memiliki nilai ekonomi cukup tinggi. Berbagai jenis tanaman pangan dan tanaman sayuran yang dibudidayakan adalah jenis tanaman semusim yang pola penanamannya bergilir. Pola ini sudah diterapkan

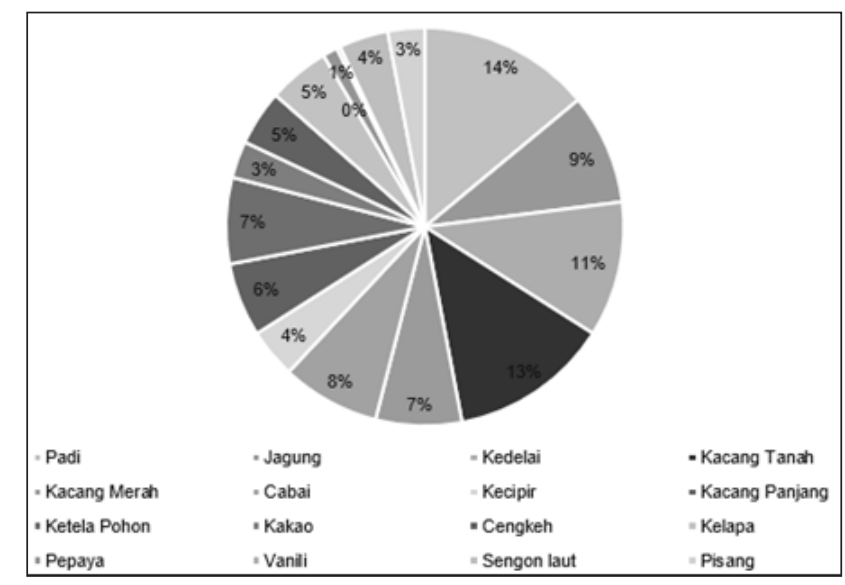

Sumber: Data Primer Penelitian 2018-2019.

Gambar 1. Jenis Tanaman yang Dibudidayakan oleh Masyarakat 
oleh masyarakat secara turun temurun dan mampu menjadi sumber penghidupan. Secara teoritis pola yang diterapkan masyarakat tersebut sudah sangat ideal, karena pergiliran jenis tanaman mampu mendorong terjadinya siklus biogeokimia secara optimal (Choudhary, et al., 2018). Siklus biogeokimia menjadi faktor utama penentu kesuburan tanah secara alamiah. Melalui pergiliran tanaman, jenisjenis tanaman memiliki kapasitas dan preferensi yang berbeda-beda dalam hal penyerapan unsur hara dan mineral tanah yang digunakan untuk pertumbuhan, perkembangan, dan reproduksi. Oleh karena itu, melalui pergiliran jenis tanaman akan semakin beragam unsur hara dan mineral tanah yang diserap, sehingga tidak akan terjadi defisit unsur hara tertentu atau bahkan akumulasi di dalam tanah. Terlebih dedaunan tua tanaman budidaya akan gugur dan berada di permukaan tanah untuk didekomposisi oleh organisme decomposer menjadi karbon organik dan unsur hara lainnya. Melalui mekanisme tersebut, siklus karbon tanah akan berlangsung dengan stabil (Pambudi, 2017). Tidak hanya itu, masing-masing jenis tanaman memiliki kandungan kimia yang bervariasi dalam daun, batang, bunga dan/atau buah yang apabila jatuh ke permukaan tanah sebelum dipanen akan berperan untuk menstabilkan siklus biogekimia dan berperan untuk mengoptimalkan lahan pertanian. Sehingga secara alamiah pola budidaya pertanian seperti ini tidak membutuhkan pemberian pupuk yang banyak, karena unsur hara akan terpenuhi melalui mekanisme alamiah.

Pada dasarnya pola yang diterapkan masyarakat tersebut sudah sangat ideal untuk diterapkan dalam hal manajemen unsur hara dan mineral tanah. Di sisi lain, pergiliran jenis tanaman juga berperan untuk mengantisipasi serangan OPT (Ormsby \& Rule, 2017). Serangan OPT dapat diminimalisir melalui pergiliran jenis tanaman (Pambudi, et al., 2019), karena beberapa jenis hama dan tumbuhan pengganggu hanya dapat tumbuh dan berkembangbiak pada waktu tertentu. Faktor lainnya dipengaruhi oleh jenis tanaman budidaya tertentu memiliki senyawa metabolit sekunder yang tidak disukai oleh hama dan tumbuhan pengganggu karena memiliki efek toksik (Masi, et al., 2017). Dengan demikian pola pertanian yang diterapkan oleh masyarakat di lokasi penelitian memiliki dua manfaat sekaligus yakni manajemen unsur hara untuk menjaga kesuburan tanah dan mengendalikan serangan OPT. Kedua prinsip tersebut menjadi faktor utama penentu keberlanjutan pengelolaan lahan pertanian. Secara mendasar petani di lokasi penelitian telah memiliki kemampuan yang sangat baik dalam mengkonservasi lahan, sehingga kedua prinsip tersebut dipraktikkan secara turun-temurun.
Praktik pertanian yang diterapkan oleh masyarakat di kawasan ini dapat bertahan hingga berabad-abad dan mampu mencukupi kebutuhan hidup mereka, karena menerapkan prinsip konservasi lahan. Oleh karena itu, prinsip konservasi lahan harus diterapkan secara luas dan menyeluruh agar keberlanjutan lahan dapat dikedepankan. Apabila tidak diterapkan tentunya lahan pertanian tidak akan dapat dikelola dalam jangka waktu yang lama dengan mempertahankan produksi yang stabil. Selain konservasi lahan, perlu diketahui bahwa di lokasi penelitian ini masyarakat memiliki kearifan lokal khususnya untuk tanaman musiman seperti tanaman pangan dan sayur yang ditanam berdasarkan perhitungan pranata mangsa. Jenis-jenis tanaman yang dipilih untuk ditanam berdasarkan kesesuaian terhadap musim dan dinamika lain seperti hama dan tumbuhan pengganggu. Waktu penanamannya pun disesuaikan dengan posisi bintang dan/atau bulan. Hal ini mengakibatkan jenis tanaman yang dibudidayakan oleh masyarakat dalam satu waktu sama/seragam. Pemilihan jenis dan waktu tanam yang sama ternyata mampu meminimalisir serangan OPT, sehingga hasil panen yang diperoleh menjadi lebih optimal (Pambudi, et al., 2019). Kearifan lokal muncul sebagai suatu bentuk sistem pertanian konvensional yang diterapkan selama ratusan bahkan ribuan tahun dan tetap aplikatif diterapkan hingga saat ini. Tentunya hasil produksinya juga tetap dapat dipertahankan dan mampu untuk memenuhi kebutuhan sehari-hari. Sistem pertanian ini menjadi salah satu kearifan lokal masyarakat di lokasi penelitian.

Walaupun demikian, ada satu halyang seharusnya menjadi perhatian perihal pemilihan jenis tanaman kaitannya dengan kesesuaian jenis lahan. Tanaman yang dibudidayakan oleh masyarakat ternyata banyak yang justru bukan tanaman asli Indonesia. Beberapa jenis tanaman berasal dari negara lain yang memiliki karakteristik iklim dan jenis lahan berbeda (Nursanti dan Adriadi, 2018). Sebagai contoh adalah padi dan Sengon Laut. Apabila dipelajari secara mendalam jenis tumbuhan yang bukan berasal dari Indonesia (tumbuhan asing) memiliki dampak negatif terhadap ekosistem lahan (Choudhary, et al., 2018). Dampak negatif tersebut terkait dengan proses pertumbuhan dan hasil panennya. Pada aspek produksi tumbuhan asing memerlukan sumber daya yang lebih banyak baik air, unsur hara, maupun aspek lain misalnya pencahayaan matahari. Dampak dari hal tersebut adalah defisit unsur hara dan air serta meningkatnya biaya produksi. Sementara hasil panennya kurang maksimal seperti di habitat aslinya, sehingga keuntungan bersih yang di dapatkan sangat rendah. Hal tersebut belum termasuk biaya 


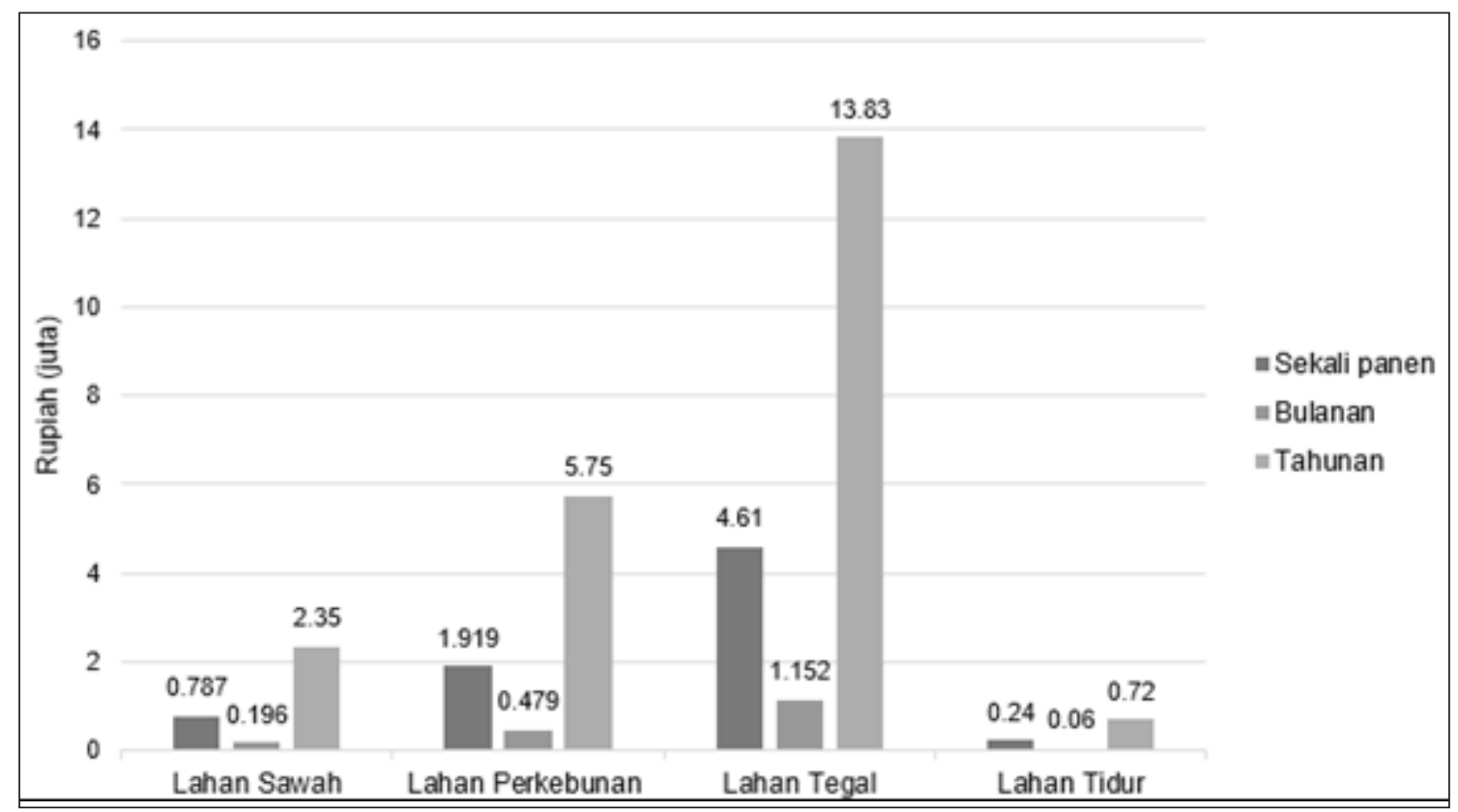

Sumber: Data Primer Penelitian 2018-2019.

Gambar 2. Hasil Produksi Pertanian Berbagai Jenis Lahan dengan Luas Lahan $300 \mathrm{~m}^{2}$

lingkungan seperti defisitnya unsur hara dan air. Jika biaya lingkungan turut dihitung bukan tidak mungkin budidaya tumbuhan asing tersebut justru menimbulkan kerugian ekonomi dan lingkungan. Berikut pada Gambar 2 ditampilkan hasil produksi berbagai jenis lahan pertanian.

Berdasarkan data hasil produksi pertanian (Gambar 2) diketahui bahwa lahan tegal memiliki produksi tertinggi mencapai Rp4,6 juta per sekali panen. Hal ini dapat terjadi karena lahan tegal dikelola oleh masyarakat dengan pola multikultur. Penerapan multikultur menjadi faktor penunjang tingginya produktivitas lahan tegal. Lahan tegal umumnya ditanami kelapa, pisang, kecipir, ketela pohon, dan bunga turi. Sementara lahan sawah yang terlihat sangat tinggi produksinya apabila dihitung bersih berdasarkan modifikasi atau penjabaran rumus perhitungan yang diadopsi dari Aini (2015) yakni (hasil panen - (biaya persiapan lahan + biaya pupuk + biaya penyiangan + biaya pengendalian OPT + biaya panen) justru memberikan nilai yang kecil, jauh di bawah lahan perkebunan dan lahan tegal. Namun demikian, pada umumnya petani tidak menghitung biaya persiapan lahan, biaya penyiangan, dan biaya panen karena ketiga aspek tersebut banyak dilakukan oleh pemilik lahan atau petani penggarap lahan, seperti halnya hasil penelitian dari Kurniawan (2010). Padahal dalam analisis usaha pertanian ketiga hal tersebut seharusnya dihitung sebagai biaya produksi untuk menentukan produksi bersih dan kelayakan usaha tani yang dilakukan. Perlu diketahui bahwa petani di lokasi penelitian secara umum dalam satu tahun melakukan penanaman sebanyak 3 kali masa tanam dan masing-masing masa tanam membutuhkan waktu 4 bulan mulai dari penanaman hingga pemanenan.

Urutan hasil produksi tertinggi kedua ditempati oleh lahan perkebunan. Produksi lahan perkebunan menunjukkan hasil yang cukup tinggi karena jenis lahan ini umumnya dikelola sebagai sampingan dan tanaman pangan yang dibudidayakan mayoritas jenis sayuran. Lahan perkebunan yang dimanfaatkan untuk budidaya sayuran memberikan kontribusi pendapatan harian dan/atau mingguan kepada petani (Edi \& Bobihoe, 2010). Misalnya adalah kecipir, tanaman ini ketika sudah tumbuh dewasa dan berbuah dapat dipanen 3 hari sekali. Artinya bahwa budidaya tanaman ini dalam jumlah yang banyak akan memberikan tambahan penghasilan kepada masyarakat. Terlebih selain buahnya kecipir juga dipanen daun mudanya sehingga 1 jenis tanaman dapat dipanen 2 jenis bagiannya yang bernilai ekonomi. Selain kecipir, lahan perkebunan juga banyak ditanami cabai, ketela pohon, pepaya, dan pisang. Tentunya semakin beragam jenis tanaman yang dibudidayakan akan memberikan nilai ekonomi yang lebih bagi petani.

Produksi terendah ditempati oleh lahan tidur karena jenis lahan ini umumnya secara sengaja tidak dikelola dengan baik oleh masyarakat karena dinilai tidak subur. Karena masyarakat menilai jenis lahan ini tidak subur, maka hanya ditanami beberapa jenis tumbuhan yang memiliki toleransi tinggi terhadap ketersediaan air dan unsur hara dengan sifat dasar hanya sebagai penutup permukaan tanah (Ariati, 2017). Beberapa di antara lahan tidur hanya ditanami dengan kelapa dan pepaya dalam jumlah yang sangat sedikit. Beberapa pemilik lahan tidur pada saat 
diwawancarai menyampaikan bahwa pepaya yang tumbuh tidak mereka tanam, tetapi secara tidak sengaja mereka membuang biji pepaya dan ternyata tumbuh. Kemudian mereka membiarkan pepaya tersebut tumbuh dan berbuah lalu dipanen untuk konsumsi sendiri dan apabila berlebih baru akan dijual. Hal ini menunjukkan bahwa pada dasarnya lahan tidur memiliki potensi untuk dikelola (Arifin, 2010), namun masyarakat enggan memanfaatkan karena mereka beranggapan dengan mengelola lahan sawah, lahan perkebunan, dan lahan tegal sudah lebih dari cukup. Sehingga lahan yang dinilai kurang subur akan dibiarkan menjadi lahan tidur. Bahkan banyak dijumpai lahan tidur di lokasi penelitian tidak dimanfaatkan sama sekali untuk keperluan pertanian dan hanya digunakan untuk pemanfaatan lain, misalnya menaruh material bangunan dan/ atau bekas bangunan, kandang ternak, dan lain sebagainya. Oleh karena itu, jenis lahan ini hampir tidak memberikan nilai ekonomi bagi masyarakat.

Lahan sawah yang dikelola sangat intensif dan menjadi lahan kebanggaan masyarakat karena berperan sebagai lahan utama penghasil makanan pokok (beras) apabila dikaji secara mendalam justru tidak sesuai secara ekologis (Thayib, 2018). Ketidaksesuaian tersebut terjadi karena pada dasarnya lahan sawah di lokasi penelitian memiliki lama penyinaran matahari \pm 9 jam per hari dengan intensitas berkisar di antara 70-86 persen per hari. Padahal padi adalah jenis tanaman C4 yang membutuhkan penyinaran matahari sebanyak mungkin untuk dapat tumbuh dengan optimal. Di sisi lain, kontur lahan di lokasi penelitian adalah lahan berbukit dan pegunungan dengan lembah ditengahnya sebagai lahan sawah komoditas padi. Secara ekologis tipelahan seperti ini idealnya ditanami jenis-jenis tanaman khas Indonesia yang bertipe C3 atau CAM dan memiliki ketahanan terhadap serangan OPT (Nazirah \& Damanik, 2015). Padi yang selama ini ditanam di lahan sawah adalah jenis tanaman yang berasal dari luar negeri dan memiliki habitat khas di daerah dengan lama penyinaran matahari $>11$ jam/hari dengan intensitas 80-92 persen per hari. Di daerah asalnya tersebut produktivitas padi mencapai 11 ton per ha, sementara di Indonesia hanya 4-6 ton per ha dan dilokasi penelitian hanya 4,42 ton per ha (Kementerian Pertanian, 2016). Rendahnya produksi padi tersebut dipengaruhi ketidaksesuaian ekologis yang mengakibatkan biaya produksi tinggi dan serangan OPT yang sangat beragam sehingga produksi padi tidak mampu maksimal seperti di negara asalnya.

Berdasarkan jenis lahan dapat diketahui bahwa jenis pengelolaan tumpang sari memberikan hasil produksi yang tertinggi. Hal ini dapat terjadi karena pengelolaan tumpang sari mengkombinasikan antara tanaman semusim, tanaman dua musim, dan tanaman menahun (pohon berkayu) (Drinkwater, et al., 2016). Melalui pola tumpang sari lahan tegal ini dapat memberikan produksi yang kontinu dan tumbuhan menahun dapat berfungsi sebagai tabungan bagi masyarakat. Tumbuhan menahun tersebut akan ditebang pada saat masyarakat membutuhkan uang untuk keperluan mendesak misalnya menyekolahkan anak menuju jenjang yang lebih tinggi atau keperluan lain. Pada jenis lahan perkebunan pola budidaya

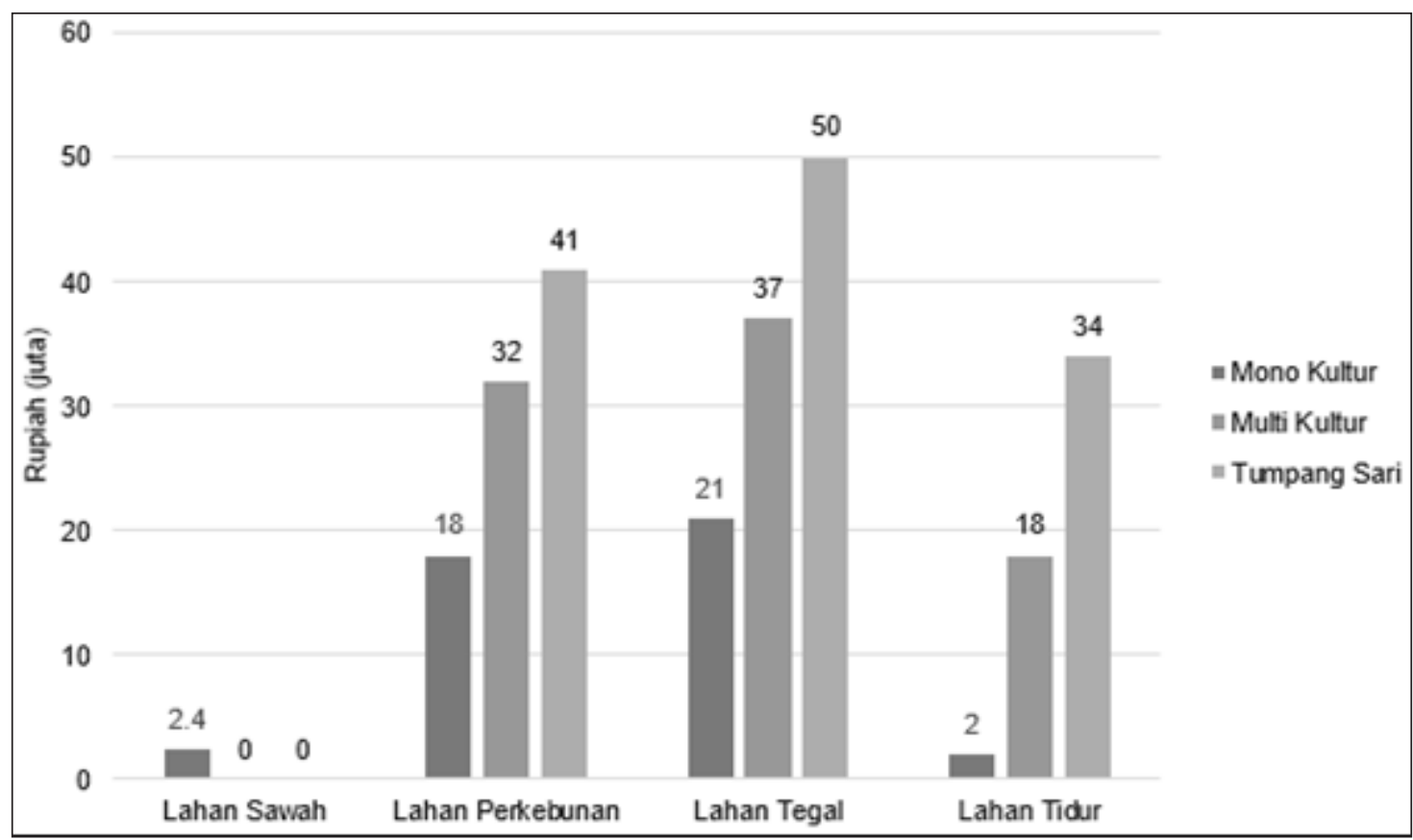

Sumber: Data Primer Penelitian 2018-2019.

Gambar 3. Produksi Pertanian Berdasarkan Jenis Pengelolaan Lahan dengan Luas $300 \mathrm{~m}^{2} /$ Tahun 
Tabel 3. Potensi Pengembangan Tumpang Sari dengan Tanaman Pokok Penghasil Gaharu

\begin{tabular}{|c|c|c|c|c|c|c|}
\hline \multirow[t]{2}{*}{ No. } & \multirow[t]{2}{*}{ Jenis lahan } & \multirow{2}{*}{$\begin{array}{l}\text { Jumlah Pohon/300 } \\
\text { m }^{2}\end{array}$} & \multicolumn{2}{|c|}{ Hasil Panen* } & \multicolumn{2}{|c|}{$\begin{array}{l}\text { Pendapatan } \\
\text { (Rp juta) }\end{array}$} \\
\hline & & & $\mathrm{Kg}$ & Rp (juta) & Bulan & Tahun \\
\hline 1. & Lahan sawah & - & - & - & - & \\
\hline 2. & Lahan perkebunan & 18 & 216 & 864 & 9 & 108 \\
\hline 3. & Lahan tegal & 30 & 360 & 1.440 & 15 & 180 \\
\hline 4. & Lahan tidur & 30 & 360 & 1.440 & 15 & 180 \\
\hline
\end{tabular}

Keterangan: *Pemanenan setelah 8 tahun masa tanam dengan produksi rerata $12 \mathrm{~kg} /$ pohon.

*Estimasi harga Gaharu grade ke-5 (Rp4 juta/kg).

Sumber: Data Primer Penelitian 2018-2019.

tumpang sari juga memberikan produksi yang tertinggi dibandingkan dengan pola monokultur dan multikultur. Demikian halnya di lahan tidur di mana budidaya dengan pola tumpang sari jauh lebih menguntungkan. Secara mendasar pola tumpang sari memang sesuai dengan kondisi iklim mikro dan kondisi ekologis di lokasi penelitian. Dengan demikian tanaman yang dibudidayakan oleh petani memiliki laju pertumbuhan yang optimal dan perkembangan yang baik, sehingga hasil panen yang diperoleh sangat baik.

Di sisi lain, biaya produksi dapat diminimalisir karena tanaman budidaya tidak membutuhkan intervensi unsur hara dan air dalam jumlah besar. Inilah pentingnya pengelolaan lahan berbasis pada kesesuaian ekologis karena jenis tumbuhan yang sesuai dengan kondisi ekologis akan mampu memenuhi kebutuhannya dari sumber daya alam yang tersedia di kawasan tersebut. Artinya bahwa jenis tumbuhan yang ditanam pada suatu kawasan lahan akan mampu tumbuh dengan baik karena secara alamiah kondisi iklim sesuai dengan karakteristik morfologi dan juga fisiologi (Mulyanti, et al., 2014). Sehingga proses fisiologis di dalam tumbuhan dapat berlangsung secara optimal dengan memanfaatkan unsur hara, air, dan intensitas cahaya yang ada. Kondisi ini berbeda apabila jenis tanaman tidak sesuai dengan kondisi ekologis, sehingga untuk menstabilkan fungsi fisiologinya harus beradaptasi secara morfologi dan juga membutuhkan sumber daya yang lebih besar. Jika hal tersebut tidak dilakukan, maka tanaman akan mengalami perlambatan pertumbuhan, kegagalan fungsi reproduktif (tidak dapat berbunga dan berbuah) atau bahkan mengalami kematian. Prinsip pengelolaan lahan berbasis kesesuaian ekologis sangat penting untuk diarusutamakan. Secara khusus di lokasi penelitian yang merupakan daerah perbukitan dan pegunungan, maka tumpang sari adalah cara yang tepat. Melalui tumpang sari, tanaman dengan karakteristik fotosintesis C3 dan CAM dapat tumbuh dan berkembang dengan sangat optimal karena ternaungi oleh tanaman menahun yang dibudidayakan. Berikut pada Tabel 3 ditampilkan data pengembangan tumpang sari.

Pengembangan pengelolaan lahan berbasis tumpang sari sangat sesuai dilakukan di lokasi penelitian karena memiliki elevasi 0-850 m dpl dan kontur lahan berbukit hingga pegunungan. Tumpang sari yang saat ini sudah diterapkan masih perlu dioptimalkan karena belum menghasilkan nilai ekonomi yang memadai bagi masyarakat. Di sisi lain jenis-jenis tanaman yang dikembangkan pada tumpang sari tergolong bukan jenis tanaman yang sesuai dengan karakteristik wilayah sehingga hasil panennya kurang optimal dan juga membutuhkan biaya cukup tinggi (Wilson \& Novell, 2016). Selain membebankan biaya produksi, jenis tumbuhan asing yang ditanam pada pola tumpang sari juga berpotensi untuk mendegradasi kualitas lingkungan. Tanaman asing tersebut adalah Akasia dan Sengon laut. Hal tersebut dapat terjadi karena jenis tumbuhan asing ini memerlukan unsur hara dan air dalam jumlah yang cukup banyak. Petani menyebutnya dengan istilah tanaman yang rakus terhadap hara, beberapa petani sudah mengetahui hal tersebut dan mulai mencoba mengurangi penanaman jenis tumbuhan asing tersebut. Namun demikian, mayoritas masyarakat belum memiliki kemampuan untuk memprediksi risiko dan dampak yang akan terjadi jika jenis tersebut masih terus ditanam, sehingga keberadaannya masih cukup mendominasi.

Jenis tumbuhan asing yang masih terus ditanam oleh masyarakat (Akasia dan Sengon laut) memang pada dasarnya memiliki nilai ekonomi tinggi. Faktor inilah yang mendorong masyarakat tergiur untuk menanam dan sejak era tahun 1990-an tumbuhan ini menjadi primadona masyarakat. Oleh karena itu, hingga saat ini keberadaannya masih sangat mendominasi kawasan lahan perkebunan dan lahan tegal (Hidayat, 2009). Di sisi lain, serapan industri yang sangat tinggi juga mendorong permintaan terus meningkat. Jenis tanaman tersebut jika tumbuh dengan optimal membutuhkan waktu 8-10 tahun 
untuk siap ditebang (Kementerian Kehutanan, 2013). Berdasarkan hasil wawancara mendalam dengan beberapa petani terdapat informasi penting yang mengindikasikan bahwa lahan pasca panen mengalami penurunan kesuburan yang sangat drastis. Setelah tanaman tersebut dipanen lahan pertanian sangat sulit dikelola untuk pemanfaatan budidaya tanaman pangan dan sayuran, karena tekstur tanah menjadi sangat keras. Selain itu, apabila di coba ditanami dengan jenis tanaman pangan dan sayur tidak dapat tumbuh dengan baik dan mengalami kematian. Sehingga lahan pasca panen hanya dapat ditanami jenis tanaman berkayu atau di biarkan tanpa tanaman (menjadi lahan tidur).

Hal tersebut perlu mendapatkan perhatian dan kajian yang lebih spesifik dan mendalam untuk memastikan dampak budidaya tanaman asing (Akasia dan Sengon laut) ini terhadap kualitas lahan. Dengan demikian, secara kualitatif dapat diketahui bahwasanya budidaya tanaman jenis ini perlu dipertimbangkan lagi karenabesarnya dampaknegatif yang mampu menghambat terwujudnya pengelolaan lahan secara berkelanjutan. Dengan demikian prinsip utama yang harus dikedepankan adalah pemilihan jenis tanaman budidaya yang memiliki kesesuaian ekologis terutama dengan indikator iklim mikro, topografi, karakteristik fotosintesis, karakteristik pertumbuhan, dan perkembangbiakan.

Penerapan budidaya tanaman berbasis kesesuaian ekologis mampu menurunkan ataubahkan menghilangkan serangan OPT. tentu sebaliknya apabila pemilihan jenis tanaman tidak didasarkan pada kesesuaian ekologis akan berdampak pada serangan OPT secara masif. Terlebih pendekatan pengendalian yang saat ini diterapkan berisiko mendegradasi kualitas lahan (Bai, et al., 2018; Rajan, 2018), sehingga risiko degradasi lingkungan semakin meningkat. Oleh karena itu, pola tumpang sari dengan tanaman pokok jenis asli Indonesia sangat penting dilakukan. Salah satu jenis tanaman menahun asli dari Indonesia adalah Aquilaria malaccensis tumbuhan ini memiliki kesesuaian ekologis dengan kawasan di lokasi penelitian. Di sisi lain tumbuhan penghasil gaharu yang dikembangkan adalah jenis tumbuhan asli Indonesia, khususnya jenis Aquilaria maleccensis memiliki fungsi bioekohidrologis sangat baik.

Fungsi bioekohidrologis adalah istilah yang menggambarkan besarnya manfaat untuk aspek biologi secara luas, ekonomi, dan hidrologi atau konservasi air. Dengan demikian fungsi serapan karbon, penyerap dan penyimpanan air, fungsi habitat, dan berbagai fungsi lain yang bermanfaat bagi lingkungan mampu diperankan oleh jenis tumbuhan ini (Susilo, et al., 2014; Pambudi, et al.,
2017). Sehingga dapat diketahui bahwa manfaat bagi masyarakat dan lingkungan yang dihasilkan dari budidaya tanaman ini sangat tinggi. Perlu diperhatikan juga bahwa jenis ini adalah tumbuhan asli Indonesia yang saat ini tercatat sebagai Appendix CITES II atau tumbuhan yang berada pada ambang kepunahan (Kemenhut, 2013). Apabila budidaya Aquilaria malaccensis dilakukan secara luas melalui pola tumpang sari dapat dipastikan dalam waktu beberapa tahun ke depan populasinya akan meningkat drastis dan berpeluang untuk mengeluarkannya dari daftar jenis tumbuhan yang terancam punah.

Secara mendasar tentunya budidaya Aqularia malaccensis berperan untuk konservasi lingkungan sekaligus memberikan nilai tambah ekonomi bagi masyarakat. Besarnya manfaat bagi lingkungan dan masyarakat akan menumbuhkan rasa kecintaan masyarakat terhadap jenis tersebut. Apabila nilai tersebut telah terinternalisasi dalam diri masyarakat tentunya mereka akan memiliki kemauan untuk merawat dengan baik. Hal lain yang memiliki peran penting adalah melalui mekanisme ini masyarakat akan memiliki rasa kepemilikan terhadap lahan termasuk segala hal di dalamnya (lingkungan), sehingga secara sadar mereka akan mampu menjaga dan melestarikannya. Poin pentingnya bahwa masyarakat akan memiliki kesadaran dan kemauan untuk melestarikan lingkungan apabila komponen di dalam lingkungan tersebut memiliki kontribusi bagi kehidupannya terutama aspek ekonomi dan ekologi.

\section{KESIMPULAN}

Pengelolaan lahan perlu dilakukan secara optimal berbasis pada kesesuaian ekologis agar mampu memberikan hasil yang optimal. Sejauh ini lahan sawah yang diunggulkan apabila dihitung nilai pendapatan bersihnya cukup kecil dan berada di bawah jenis lahan tegal dan perkebunan. Rendahnya nilai produksi lahan sawah diakibatkan oleh jenis tanaman budidaya tidak sesuai dengan kondisi ekologis sehingga mengakibatkan biaya tanam yang sangat tinggi, di sisi lain serangan OPT juga masif, sehingga produksinya tidak dapat optimal. Sementara itu, jika ditinjau dari jenis pengelolaan lahan, usahatani tumpang sari memberikan hasil produksi tertinggi. Namun demikian perlu diarusutamakan pengelolaan lahan berbasis kesesuaian ekologis untuk memberikan hasil yang optimal dengan pengelolaan yang efisien. Selain itu, pengelolaan berbasis kesesuaian ekologis mampu mengurangi risiko degradasi lahan, serangan OPT, dan efisiensi sumber daya alam.

Salah satu strategi yang harus diutamakan dalam pengelolaan lahan adalah melalui pola tumpang 
sari dengan tanaman utama Gaharu (Aquilaria maleccensis) sebagai tanaman penghasil gaharu. Budidaya tanaman ini mampu memberikan manfaat bagi lingkungan untuk menyerap $\mathrm{CO}_{2}$, penyerap dan penyimpan air, mengikat partikel tanah agar tidak mudah longsor atau erosi, dan menyediakan fungsi habitat bagi organisme (konservasi), selain itu juga manfaat ekonomi untuk mengoptimalkan pendapatan masyarakat. Pada prinsipnya pengelolaan lahan pertanian apabila dilakukan berdasarkan kesesuaian ekologis akan memberikan manfaat yang sangat besar bagi kehidupan sosial ekonomi masyarakat dan lingkungan.

\section{DAFTAR PUSTAKA}

\section{Buku}

Biel, R. (2016). Sustainable food systems. London: UCL Press.

Dinas Koperasi, Perindustrian, dan Perdagangan Kabupaten Pacitan. (2015). Daftar industri di Pacitan. Pacitan: Dinas Koperasi, Perindustrian, dan Perdagangan Kabupaten Pacitan.

Drinkwater, L., Friedman, D., \& Buck, L.E. (2016). Systems research for agriculture: Innovative solutions to complex challenges. Brentwood, MD.: Sustainable Agriculture Research and Education (SARE) Program and National Institute of Food and Agriculture, U.S. Department of Agriculture.

Edi, S., \& Bobihe, J. (2010). Budidaya tanaman sayuran. Jambi: Balai Pengkajian Teknologi Pertanian Jambi.

FAO (2016). Influencing food environment for healthy diet. Rome: Food and Agriculture Organization of the United Nations.

Global Panel on Agriculture and Food Systems for Nutrition. (2016). Food systems and diets: Facing the challenges of the 21st century. London: Springer.

IPES. (2016). From uniformity to diversity: A paradigm shift from industrial agriculture to diversified agroecological systems. International Panel of Experts on Sustainable Food systems. Louvainla-Neuve (Belgium): IPES.

Kartodihardjo, H., \& Supriono, A. (2000). Dampak pembangunan sektoral terhadap konversi dan degradasi hutan alam: Kasus pembangunan HTI dan perkebunan di Indonesia. Bogor: CIFOR.
Kementerian Kehutanan. (2013). Masterplan penelitian dan pengembangan Gaharu 20132023. Jakarta: Kementerian Kehutanan.

Kementerian Pertanian. (2016). Statistik pertanian 2016. Jakarta: Kementerian Pertanian.

Pagiola, S. (2000). Land use change in Indonesia. Environmental Department, World Bank.

Susilo, A., Kamila, T., \& Santoso, E. (2014). Panduan lapangan pengenalan jenis pohon penghasil Gaharu Aquilaria spp. di Indonesia. Jakarta: Pusat Penelitian dan Pengembangan Konservasi dan Rehabilitasi dengan International Tropical Timber Organization (ITTO)-CITES Phase II Project.

Thayib, M.H. (2018). Ekologi: Mempertautkan ilmu-ilmu alam dengan ilmu sosial. Jakarta: Lembaga Penerbit Fakultas Ekonomi Universitas Indonesia.

Widianto., Suprayogo, D., Noveras, H., Widodo, R.H., Purnomosidhi, P., \& Noordwijk, M.v. (2004). Alih guna lahan hutan menjadi lahan pertanian: Apakah fungsi hidrologis hutan dapat digantikan sistem kopi monokultur? Bogor: World Agroforestry Centre.

\section{Jurnal}

Aini, Y. (2015). Analisis keuntungan usahatani padi sawah di Kecamatan Rokan IV Koto. Jurnal IImiah Cano Economos, 4(1), 121-130.

Akpoti, K., Kabo-bah, A.T., \& Zwart, S.J. (2019). Agricultural land suitability analysis: State-ofthe-art and outlooks for integration of climate change analysis. Agricultural Systems, (173), 172-208.

Ariati, P.E.P. (2017). Produksi beberapa tanaman sayuran dengan sistem vertikultur di lahan pekarangan. Agrimeta, 7(13), 76-86.

Bai, Z., Caspri, T., Gonzalez, M.R., Batjes, N.H., Mäder, P., Bünemann, E.K., Goede, R.d., Brussaard, L., Xu, M., Ferreira, C.S.S., Reintam, E., Fan, H., Mihelič, R., Glavan, M., \& Tŏth, Z. (2018). Effects of agriculture management practices on soil quality: A review of long-term experiments for Europe and China. Agriculture, Ecosystem and Environment, (265), 1-7.

Béné, C., Oosterveer, P., Lamotte, L., Brouwer, I.D., Haan, S.D., Prager, S.D., Talsma, E.F., \& Khoury, C.K. (2019). When food systems meet sustainability-Current narratives and implications for actions. World Development, (113), 116-130. 
Bonfante, A., Langella, G., Mercogliano, P., Bucchignani, E., Manna, P., \& Terribile, F. (2018). Science of the total environment a dynamic viticultural zoning to explore the resilience of terroir concept under climate change. Science of the Total Environment, (624), 294-308.

Choudhary, M., Datta, A., Jat, H.S., Yadav, A.K., Gathala, M.K., Sapkota, T.B., Das, A.K., Sharma, P.C., Jat, M.L., Singh, R., \& Ladha, J.K. (2018). Changes in soil biology under conservation agriculture based sustainable intensification of cereal systems in Indo-Gangetic Plains. Geoderma, (313), 193-204.

Gaffney, J., Challender, M., Califf, K., \& Harden, K. (2019). Building bridges between agribusiness innovation and smallholder farmers: A review. Global Food Security, (20), 60-65.

Haddad, L., \& Hawkes, C. (2016). A new global research agenda for food. Nature, (540), 30-32.

Hidayat, A. (2009). Sumberdaya lahan Indonesia: Potensi, permasalahan, dan strategi pemanfaatan. Jurnal Sumberdaya Lahan, 3(2), 107-117.

Karuniasa, M., \& Pambudi, P.A. (2019). Transition of primary forest to secondary forest and the impact for water resources conservation. Journal of Environmental Science and Sustainable Development, 2(1), 15-25.

Kihoro, J., Bosco, N.J., \& Murage, H. (2013). Suitability analysis for rice growing sites using a multicriteria evaluation and GIS approach in Great Mwea Region, Kenya. SpringerPlus, 2(265), 1-9.

Sahara, D., \& Kushartanti, E. (2019). Kajian sistem tanam usaha tani Padi Gogo di lahan kering Kabupaten Boyolali, Jawa Tengah. Jurnal IImu Pertanian, 24(1): 65-72.

Lund, C. (2017). Predatory peace, Dispossession at Aceh's oil palm frontier. J. Peasant Stud, 1-22.

Masi, M., Cimmino, A., Boari, A., Tuzi, A., Zonno, M.C., Baroncelli, R., Vurro, M., \& Evidente, A. (2017). Colletochlorins $E$ and F, New phytotoxic tetrasubstituted pyran-2one and dihydrobenzofuran, isolated from Colletotrichum higginsianum with potential herbicidal activity. J. Agric. Food Chem, (65), 1.124-1.130.

Montgomery, B., Dragićević, S., Dujmović, \& Jozo, M.S. (2016). A GIS-based logic scoring of preference method for evaluation of land capability and suitability for agriculture. Computers and Electronics in Agriculture, (124), 340-353.
Mosleh, Z., Salehi, M.H., Amini F.A., Jafari, A., Mehnatkesh, A., \& Esfandiarpoor B.I. (2017). Sustainable allocation of agricultural lands and water resources using suitability analysis and mathematical multi-objective programming. Geoderma, (303), 52-59.

Mourao, P.R., \& Martinho, V.D. (2019). Forest fire legislation: Reactive or proactive? Ecological Indicators, (104), 137-144.

Mourao, P.R., \& Martinho, V.D. (2016). Discussing structural breaks in the Portuguese regulation on forest fires-An economic approach. Land Use Policy, (54), 460-478.

Mulyanti., Karim, A., \& Sugianto. (2014). Penataan kawasan tanaman pangan dan perkebunan berbasis kesesuaian lahan di Kecamatan Labuhan Haji Timur Kabupaten Aceh Selatan. Jurnal Manajemen SUmberdaya Lahan, 4(1), 520-526.

Nazirah, L., \& Damanik, B.S.J. (2015). Pertumbuhan dan hasil tiga varietas Padi Gogo pada perlakuan pemupukan. Jurnal Floratek, (10), 54-60.

Nurhayati, I.N., Brata, N.T., \& Rochana, T. (2017). Etnoekologi masyarakat penambang emas rakyat di Desa Cihonje Kecamatan Gumelar Kabupaten Banyumas. Solidarity, 6(2): 156-166.

Nurrani, L., \& Tabba, S. (2013). Persepsi dan tingkat ketergantungan masyarakat terhadap sumberdaya alam Taman Nasional Aketajawe Lolobata di Provinsi Maluku Utara. Jurnal Penelitian Sosial dan Ekonomi Kehutanan, 10(1), 61-73.

Nursanti., \& Adriadi, A. (2018). Keanekaragaman tumbuhan invasif di kawasan Taman Hutan Raya Sultan Thaha Saifuddin, Jambi. Media Konservasi, 23(1): 85-91.

Ormsby, M., \& Rule, E.B. (2017). A review of global instruments to combat invasive alien species in forestry. Biological Invasion, (19), 3.355-3.364.

Pambudi, P.A., \& Waryono, T. (2018). Life cycle assessment on dryland paddy farming in Ngadirojo District, Pacitan. E3S Web of Conferences, (74)07001, 1-7.

Pambudi, P.A., Utomo, S.W., Waryono, T., \& Hartono, D.M. (2019). Weed management in dryland paddy farming for environmental conservation. IOP Conference Series: Earth and Environmental Science, (239), 1-7. 
Rajan, R. (2019). What drives forest degradation in the Central Himalayas? Understanding the feedback dynamics between participatory forest management institutions and the species composition of forests. Forest Policy and Economics, 95(17), 85-101.

Rótolo, G.C., Montico, S., Francis, C.A., \& Ulgiati, S. (2015). How land allocation and technology innovation affect the sustainability of agriculture in Argentina Pampas: An expanded life cycle analysis. Agricultural Systems, (141), 79-93.

Smith, P. (2013). Delivering food security without increasing pressure on land. Global Food Security, 2(1), 18-23.

Sriyanto. (2007). Kondisi Lingkungan Hidup di Jawa Tengah dan Prospek Pembangunan ke Depan. Jurnal Geografi, 4(2): 107-113.

Tsonkova, P., Böhm, C., Quinkenstein, A., \& Freese, D. (2013). Ecological benefits provided by alley cropping systems for production of woody biomass in the temperate region: A review. Agrofor. Syst, (85), 133-152.

Wilson, M.H. \& Lovell, S.T. (2016). Agroforestry-The next step in sustainable and resilient agriculture. Sustainability, 8(6), 574, 1-15.

\section{Laporan}

Pambudi, P.A. (2017). Analisis perbandingan serapan karbondioksida $\left(\mathrm{CO}_{2}\right)$ tumbuhan di Kawasan Ranu Pani Taman Nasional Bromo Tengger Semeru pada tahun 2015 dan 2016 sebagai Sumber Belajar Biologi. Malang: Research Report Universitas Muhammadiyah Malang.

\section{Makalah dan Prosiding}

Arifin, H. S. (2010). Optimalisasi pemanfaatan pekarangan untuk mendukung ketahanan pangan rumah tangga. Makalah disajikan pada diskusi tematik memperkuat basis ketahanan pangan rumah tangga. Bogor: Dramaga.

Pambudi, P.A., Rahardjanto, A., Nurwidodo., \& Husamah. (2017). Analisis serapan karbondiosida $\left(\mathrm{CO}_{2}\right)$ tumbuhan di Blok Puyer Kawasan Ranu Pani Taman Nasional Bromo Tengger Semeru (TNBTS) pada Tahun 2016. Prosiding Seminar Nasional III Tahun 2017 "Biologi, Pembelajaran, dan Lingkungan Hidup Perspektif Interdisipliner". Prodi Pendidikan Biologi-FKIP bekerjasama dengan Pusat Studi Lingkungan dan Kependudukan (PSLK) Universitas Muhammadiyah Malang, tanggal 29 April 201. 